\title{
Considerations of Distance Education Integration: A Qualitative Study
}

\author{
Jennifer L. Styron \\ Shuyan Wang \\ Ronald A. Styron, Jr. \\ The University of Southern Mississippi, USA
}

\begin{abstract}
As higher education institutions determine whether or not to initiate or expand distance education offerings, there are many considerations and levels of decision making that need to be measured. This study investigated the role of key administrators at the departmental chair and dean levels in expanding distance education offerings. Findings of this study included faculty and student considerations, resources and external support, and integration costs of distance education offerings as major considerations within distance education decision making. Furthermore, the need for realistic timelines, planning for the associated costs of distance education offerings, and current tenure and promotion policies are discussed. The findings of the study provide insight into the planning, preparation, development, and implementation stages of distance education offerings.
\end{abstract}

Keywords: Distance Education, Administrative Decision Making, Technology Integration, Higher Education Faculty, Resources

\section{Introduction}

Distance education has become a controversial topic within educational settings throughout the United States, particularly within sectors of post-secondary education. As higher education institutions determine whether or not to initiate or expand distance education offerings, there are many considerations and levels of decision making that should be considered. In many institutional settings it is not uncommon to find lengthy internal approval processes for distance education programs starting with a faculty member and filtering up through a program coordinator, department chair, college associate dean, college dean, provost, and president before a determination is made. Not only does this process feature multiple key administrators in the decision making process, but the process is also extremely time consuming, which presents challenges to those institutions looking to advance their distance education offerings. Furthermore, distance education technology is rapidly changing and there is a perceived pressure to initiate distance offerings before the programs are offered by competing institutions. Current literature focuses on institutional bureaucracies at the apex of decision making structures rather than looking at department and dean level administrative and decision making processes of distance education. This research study explores departmental and dean level decision making as related to distance education. 


\subsection{Literature Review}

Administrators and department chairs must take into account a vast array of considerations when trying to increase educational technology use and distance education offerings. Utilizing data found at The National Center for Education Statistics (NCES) Web site, the researchers identified four factor components that impacted distance education offerings. These factors included faculty concerns, institutional barriers, lack of funding/costs, and resources and external support. These factors helped to organize the decision making process pertaining to distance education and the expansion of distance education offerings. By better understanding administrative challenges and decision making processes, faculty and institutions need to be better informed of the multi-dimension complexities of incorporating technology and distance education offerings within higher education entities.

The cost of higher education continues to be a growing challenge for administrators. Inflated student tuition fees, costs associated with student services, increased student/ teacher ratios, inadequate teaching and learning facilities, and the diversity of student bodies are modern-day institutional concerns. In conjunction with increasing costs, higher education entities are struggling to secure funding to support general operations. State and Federal monetary support continues to decrease; therefore, administrators are looking to various technologies to help alleviate the financial barriers created by reduced funding. Administrators are also considering new strategies for increasing student enrollment based on improving student access and convenience. For example, some institutions have integrated online student portals that include the ability to speak with advisors online and add, edit, and drop classes. Additionally, some administrators see technology as a vehicle to recruit more students while keeping costs down. Although various technologies, both administrative and instructional, are offered to faculty, many choose not to integrate those technologies (Surry \& Land, 2000). This lack of usage is sometimes compounded by the negative attitudes and beliefs of administrative leaders regarding educational technology. To facilitate the use of technology, administrators should have a vision of how educational technology will impact their school. Anderson and Dexter (2005) found "technology leadership to have the largest correlation with technology outcome" (p. 70). This further suggests that by exploring administrative attitudes and decision making processes, institutions would develop a further understanding of the complexities of starting and expanding distance education offerings.

Faculty concerns should also be considered when determining whether or not to begin or expand distance education offerings. These concerns are heightened over the perceived pressure faculty feel from administrators to implement technology and distance education courses. While technology and distance education implementation is often expected, incentives are not considered to help motivate faculty (Bower, 2001). In 2000, the National Education Association found that " $63 \%$ of faculty were given similar compensation for distance education as face-to-face courses" (Bower, 2001, p. 1). Determining and defining incentives are critical, if any, given at the departmental and college level to help motivate faculty to expand distance education offerings. Studies indicate that faculty motivation is a significant indicator of technology implementation, thus determining whether or not distance education offerings will expand (Bower, 2001; Surry and Land, 2000).

Institutional support continues to be a concern for faculty when implementing or 
expanding distance education courses (Bower, 2001). Motivators and support from institution are key factors in assisting faculty to develop distance education offerings. Factors such as release time, compensation, and authorship of course materials are among initial institutional considerations. Furthermore, many tenure and promotion policies still do not include technology use and/or distance education course creation. If institutions seek to expand distance education offerings, such areas should be explored in a collaborative environment and policies and procedures should be implemented accordingly.

Additionally, lack of resources can play a significant role in determining whether or not faculty implement technology. In a 2001 study, researchers Shim and Shim found that inadequate facilities had a significant impact on faculty technology integration. Training on the utilization of technological resources and their integration into classroom instruction is also a factor in determining the success of distance education efforts. Providing adequate facilities and professional development will help ensure that faculty are motivated, prepared, and confident when integrating technology, thereby, increasing the likelihood of successful distance education development and participation.

How administrators and department chairs develop techniques to provide revenue streams to support and encourage development of distance education offerings might also lend insight into distance education offerings that an institution provides. As one might expect, lack of adequate funding severely hampers technology development and usage. By discovering how administrators and department chairs plan for the purchase, support, and maintenance of technology, new insights into these processes will be explored. External support from accrediting agencies and governing bodies of education can also influence administrative and departmental decisions regarding distance education offerings. Ultimately, therelationships between these agencies and governing bodies in relation to administrative decision making should be explored.

\subsection{Purpose of the Study}

The purpose of this study was to investigate the role of key administrators at the departmental chair and dean levels in expanding distance education offerings. The researchers contend that the findings of this study will help administrators plan and develop distance education offerings. To better understand the processes required to create and expand distance education offerings, exploring the experiences of administrators and departmental chairs, specifically the challenges and barriers they have faced is necessary. Examining support needed at the institutional level to build successful distance education programs is another area of concern. Utilizing factors developed through a factor component analysis and literature review, four areas were studied: (1) faculty concerns, (2) institutional barriers, (3) lack of funding/costs, and (4) resources and external support. This study explored whether or not these factors impacted administrative decision making regarding distance education offerings and if the themes found within the study were supported through previous literature and research on administrative decision making in distance education. Research questions for this study included:

1. What types of factors were considered in administrative decision making processes?

2. What levelofimportance did each factor have in influencing administrators when determining the expansion of distance education offerings? 
Distance education offerings in this study included, but were not limited to online programs, online courses, hybrid courses, and video correspondence courses.

\subsection{Significance of the Study}

Through the understanding of how the four factors supported and/or inhibited administrators' decisions regarding distance education offerings, higher education institutions will be able to better determine the feasibility of distance education programs. Findings of the study will provide pertinent information that could influence future decision making processes regarding distance education, allow for collaborative discussions about current barriers, and provide insights when discussing distance education offerings. The findings from this study will also allow upper-level administrators to explore central themes to identify what types of challenges key administrators are facing regarding distance education offerings. By understanding the factors and influences at the department and dean levels, the university will be able to address and make changes to processes as needed. The knowledge gained from this study will provide insight specifically to the institution involved in the research project and serve as a starting point for future research to explore if commonalities exist within similar regional areas.

\section{Methodology}

A qualitative case study formed the methodological framework of this study. This method was appropriate because the researchers studied a particular phenomenon in its natural setting (Punch, 2000) and attempted to interpret the phenomenon in terms of the meanings people brought to the situation (Guba \& Lincoln, 1994). Homogeneous sampling was utilized with the overall goal of extending the research available for influential decision makers on the impact that the four key factors had on distance education offerings. The researchers studied a specific group of campus administrators and department chairs to discover what types of factors influenced decision making processes regarding distance education offerings. This allowed the researchers to develop an understanding and interpret the uniqueness of the individuals within their administrative environment to better understand the phenomenon.

Four factors were explored with administrators to determine commonalities and themes that allowed for a better understanding of how these factors influenced decision making, which in turn posed implications for distance education offerings. The levels of importance for each factor were self-determined by each individual participant based on previous administrative experiences specific to distance education. Interrelated themes in levels of importance were developed to determine which factors had high levels of importance.

Because of time limitations and the restricted nature of the topic being explored, observations on site were not possible. Any documentation such as emails, telephone calls, and conversations could not be acquired for the purposes of the research. The findings reported are based solely upon the interviewees' statements to the guided questions. Participants were provided a list of guided questions through email, before they participated in the personal interviews. The reason for performing this was to provide them with sufficient preparation for the interview.

\subsection{Research Setting and Participants}

The research setting was a southeastern research-intensive university located in the United States. The university includes over 90 different academic programs and over 15,000 
students. There are two main campuses of the university. One campus serves as the main campus and the other is a regional campus located approximately 70 miles south of the main campus. The university offers three undergraduate online programs, seven doctoral online programs, seven hybrid programs (online and face-to-face classes), and several online certificate programs. There are approximately 600 courses offered online each term. The university's technology resource center located on the main campus provides technology support and training to all faculty members on both campuses.

The research participants included four individuals with expertise in their respective academic discipline. Each participant was intentionally selected based on his/ her leadership role within the institution. Background information about each participant follows in alphabetical order to help readers understand their experiences. Pseudonyms have been used to protect the participants' identities.

Dr. A, a male professor, has 7 years of higher education experience. Of the 7 years within higher education, Dr. A had been in leadership roles for 5 years, serving as follows: program coordinator, department chair, and interim associate dean. Dr. A has been involved in both the development and decision making processes regarding distance education offerings at both the departmental and college level over the 5 years that he served in leadership roles.

Dr. B, a female professor, has 9 years of higher education experience, serving in leadership roles for 8 years. Dr. B has served as a department chair, an associate dean, and an interim dean. Dr. B has also been involved with the development and direction of distance education offerings. Dr. B has had teaching and course development experience in building online and hybrid courses, primarily at the institution's regional campus.

Dr. C, a female professor, has 5 years of higher education experience, with 4.5 years in leadership roles. She has served as a program coordinator and department chair. Dr. C was heavily involved in the development of curriculum and online courses for a fully online master's degree program and has experience in teaching distance education courses, specifically online courses.

Dr. D, a male professor, has been working in higher education for 7 years and has held leadership roles all of these years. He has served as a program coordinator, assistant chair, and department chair. Dr. D was also charged with the overall development and creation of a fully online master's degree program and has been involved in pilot studies that integrated various instructional technologies within online courses.

\subsection{Data Collection and Analysis}

To allow for greater flexibility, semistructured, in-depth, face-to-face individual interviews were the method of data collection for this study. This method was determined to be more likely to yield a greater amount of useful information than structured interviews (Leedy \& Ormrod, 2005). By interviewing participants, the researchers were able to take an in-depth look at the departmental and college-level processes to better understand the relationship between decision making strategies regarding distance education offerings and administrative factors that impacted those decisions. The interviews were conducted on campus and ranged from 18 to 46 minutes per person. All interviews were audio taped and field notes were taken to ensure the accuracy of subsequent transcription. Guided interview questions were identical for all participants 
(refer to Appendix A). This method of interviewing allowed for the exploration of the four factors and actual experiences that administrators were facing.

Institutional review board approval was obtained prior to conducting this qualitative study. Each participant was asked to sign a consent form prior to his/her interview. In addition, participants were e-mailed the list of guided questions prior to the interview so that they had ample time to fully reflect upon their experiences. All audio and field notes were transcribed for data analysis. After transcription, a hand analysis was conducted to identify common themes and descriptions using lean coding. Major and minor themes were constructed based on multiple re-readings of the data. Findings from the interview were then summarized for the purposes of this study.

\section{Findings and Interpretations}

The identified themes in this study were grouped in six major categories: (a) distance education offerings, (b) faculty considerations and incentives, (c) student considerations, (d) resources and external support, (e) lack of funding and costs, and (f) administrative characteristics and considerations. Each category is discussed in-depth below.

The level of importance for each factor was self-determined based upon the impact each factor had in participants' experiences with distance education. While each factor was discussed and explored, all administrators stressed the importance of faculty and student considerations within their decision making processes and felt as though these factors were extremely important in the expansion of distance education offerings. Institution bureaucracy was also emphasized throughout the interviews conducted as an important consideration in distance education expansion.

\subsection{Distance Education Offerings}

The distance education offerings, as described by the participants, included fully online programs (with one currently in the development stage), an array of courses that were offered in hybrid or online formats, and minimal videoconferencing correspondence courses that were offered between the two university campuses. An important note emphasized by the participants was the university's unique definition of online courses, explained by Dr. A as "a course that has greater than $50 \%$ of the course delivered online." The implication for this definition means that a traditional 16 week course labeled as an online course could require several face-to-face class meetings. With such a broad definition of online courses, identifying course expectations for students prior to enrollment was extremely challenging for administrators. Many out-ofstate students were taken by surprise to find an "online" course required seven campus visits.

All online programs utilized Blackboard as the course management system for the delivery of courses. Horizon Wimba, a collaborative learning software, was also used by some professors for courses and online programs as an embedded tool. One online program piloted the integration of Web 2.0 tools such as Blogs, Wikis, and Social Networking sites within courses. Drs. B and C were part of a development team that moved a traditional (face-to-face) program to fully online, providing invaluable experiences with the process of starting distance education offerings. Drs. B and $\mathrm{C}$ acknowledged decision making processes including an examination of the pedagogy of online content delivery based on individual faculty philosophies, prior content delivery experience, workload requirements for cohorts, program uniformity, course consistency, and aesthetic features found within each course. Dr. $\mathrm{D}$ described this process as "tedious" and found 
getting faculty on board extremely challenging. Three of the participants explained that having upper-administrative support, such as that of the provost and president, helped administrators gain faculty buy-in for the online program. Dr. D stated, "Once that [upper-administration support] became known that the higher levels of administration were behind this effort, it strengthened the department's position for developing the online program."

\subsection{Faculty Considerations and Incentives}

Participants discussed faculty considerations, which included tenure and promotion policies and procedures, buy-in, and openness/ resistance to online learning and academic rigor. According to the participants, incentives included compensation for developing or teaching online courses, faculty recognition, benefits gained from partnerships with private companies, and financial support from the dean's office.

Participants classified faculty into three groups, "the speed boat group, the moderate learner group, and the resistant group." The speedboat group was identified as "faculty who want more technology and are motivated to incorporate it [technology] into his/her curriculum." The moderate learner group was defined as "those faculty who are not as adept as the speed boat faculty, but are still inclined to incorporate technology at their own learning pace." Finally, the resistant group was identified as "faculty who are not going to do anything [in regards to technology integration]." These three different group types were discussed throughout all interviews.

The most frequently mentioned faculty concern voiced by the participants in this study was the recognition of efforts in the development and implementation of distance education offerings. Participants reported that there were no tenure and promotion policies or procedures that rewarded faculty for developing online courses or implementing technologies into the current curriculum. Dr. A expressed concern by stating, "There is a prevailing mentality that you have to be a good teacher and you have to provide a lot of service but if you do not publish, you are not going to be promoted or retain your job." Additionally, tenure and promotion policies and procedures were also a major concern of this college's current administration, because $70 \%$ of the faculty within the college were junior faculty working toward tenure status.

Faculty buy-in was another commonly explored faculty consideration. Without faculty support, the current offerings, as well as any new offerings, would not be successful. Three of the participants (Drs. A, B, and C) identified faculty as highly influential in the development of online courses and programs. As Dr. B stated,

If a department's faculty are primarily resistant to technology, even when there is a market for an online program, you have to wait until you get faculty to support it [technology], otherwise it will not be successful. You have to have faculty buy-in before you move forward with the technology.

Administrators must be aware of the fine line between encouraging distance education development and mandating distance education development. Dr. B stated, "It's really difficult sometimes to implement new phases of technology because even when those at the top [upper administration] say they want to implement technology there may still be resistance at lower administrative levels blocking your efforts." Dr. D acknowledged 
the importance of faculty buy-in by stating, "Faculty are going to struggle, fight, argue; and maybe that's a natural process. But even so, you'll be very satisfied with the product if you realize that this is all part of the natural growth process."

Faculty openness was another identified consideration of administrators when making decisions regarding distance education offerings. Dr. B described a noted shift in faculty attitudes toward online learning from resistant to open. With this new attitude shift, the department was able to move forward in the development of a fully online program, which had been discussed but not implemented during the past few years. Dr. D supported the need for faculty openness by stating, "Not all faculty share the same online enthusiasm. There is a part of academia that embraces the old, the scholarly, the traditional, the set in the ways, and there is a lot to be said for that." The administrator should know the attitudes and perceptions faculty associate with distance education offerings prior to developing and/ or expanding distance education offerings. For example, in the development of an online program, again Dr. D found that faculty in the major content area were unified in the decision to move forward on the development of the online degree; however, Dr. D also found difficulty in working with supporting program areas for that particular degree. The administrator involved in this situation would have been better prepared for distance education integration if he/she had known the attitudes and perspectives of the supporting program faculty prior to entering the developmental process.

Rigor and academic quality within online courses and programs is still questioned by faculty, as many believe that rigor is diminished in distance education offerings. Three of the participants (Drs. A, B, and C) identified faculty concerns regarding the quality of online courses and programs, with two participants (Drs. B and C) sharing that some faculty have a mindset that online courses and programs are a way of "dumbing down the curriculum." Dr. C briefly described the artificial and real barriers, "when people [faculty] put a course online and are involved in working with students online, they actually see that some of the barriers they thought were real were actually perceived." Dr. B believed that current students in higher educational settings were like consumers, and if the college did not implement distance education programs due to perceptions of rigor, the college could possibly "high standard itself out of business." Additional faculty concerns expressed by individual participants included a fear of brick and mortar schools closing, the time constraints involved in developing instructional materials, and effectively teaching the content needed for the purposes of the course.

Faculty incentives identified by the participants included financial compensation, faculty recognition at the collegiate level, and the benefits of partnerships. All four participants mentioned that faculty are eligible for financial compensation from the university in the amount of $\$ 1,000$ for development of an online course. Furthermore, the university also financially compensated faculty for the delivery of an online course. The administrators involved in this study provided recognition to faculty who were involved with integrating technology into the curriculum. One type of recognition utilized by administrators to provide faculty recognition was the provision of letters of commendation that faculty could place in his/her dossier. This type of recognition was provided for the purposes of tenure and/or promotion to ensure that the faculty member was recognized for his/her innovative efforts in integrating technology.

Partnerships have also been developed within the departments and colleges. For 
example, a global interactive whiteboard company partnered with one of the Colleges to provide equipment for faculty interested in developing flipchart resources. This partnership provided faculty with the tools and technical training needed to successfully develop class lessons. Additionally, by incorporating such technology use with collegiate students, future teachers will be well trained on how to effectively integrate whiteboard technology into the classroom. The creation of partnerships with vendors and private companies has been one venue for administrators to provide free or discounted equipment, training, and support to faculty interested in technology usage.

\subsection{Student Considerations}

Student matters were not an identified factor; however, all four participants discussed considerations that took into account specific student needs. Those specific needs included increased online offerings, outreach convenience, and student social networking.

The most frequently cited student consideration was convenience. Three of the four participants (Drs. A, B, and C) identified this as a primary consideration when making decisions regarding the creation and/or expansion of distance education offerings. Dr. A described how convenience factors impact student needs as most of their graduate students "must support their families, work a full-time job, as well as take classes." Dr. B expressed concern that failing to integrate distance education offerings into degree plans would lead to a decrease in the student enrollment due to the convenience factor as framed by Dr. A in the previous sentence. Dr. B went on to say, "Students today can get the courses they want at their homes. They don't have to drive to campus, fight the traffic, and fight for parking spaces only to take a class where they might not learn anymore than they would in an online course."
Participants in the study also utilized technology to reach students locally, nationally, and internationally. The state's higher education system has a list of central goals, one of which is to increase engagement of students in the teaching and learning process as active learners. Of course, one way to reach this goal is through online learning, as student engagement is an essential part of this process. Further compounding the challenge of student engagement is the commute to the university. Many students enrolled at the institution are located in remote areas, further hindering their opportunities to attend courses in person on campus. All interviewees identified the creation and expansion of the college's distance education offerings as a mechanism for attracting nontraditional and geographically dispersed students to the university. Many of these students might not be afforded the opportunity to attend traditional style courses due to work commitments, the commute to school, and the cost of transportation.

Increased enrollment was also an area of interest to the administrators in this study. Since the creation of the online programs within the department and college, Dr. D acknowledged an increase in national and international students attending the institution, with particularly high enrollments from "the states of Alaska and South Carolina, as well as international interest from Department of Defense schools and American schools located in eastern Europe." It was in great part through distance education offerings that the college generated additional student credit hours, increased tuition revenue, and provided students with more flexibility in their coursework.

Students' interest should also be taken into consideration when determining whether or not to expand distance education offerings. Three of the participants expressed the need to meet 
students at their technological readiness level. As Dr. A explained,

The new generation of students has great technological expertise and expectations. Students expect multiple technologies to be integrated into coursework. By providing professors with technology integration training, assuming they will use the skills and knowledge obtained in this training, educators are better positioned to attract those who Howe and Strauss (2003) refer to as Millennial students to our classes.

Based on their administrative experiences, Drs. C and D expressed concern that they needed improvement in the area of students' interest and believed that multiple delivery options for course content should be provided to ensure that every student had a personalized learning environment with multiple technologies. Administrators also identified various perspectives that students have on course delivery; some students, usually ages 30 and older, prefer face-to-face courses and others, usually under the age of 30 , prefer online courses. Ideally, distance education offerings should afford students the ability to select the type of course or program that best suits their individual needs based on multiple offerings in various online delivery formats.

Students' socialization within the learning environment was also a consideration for distance education offerings. Making sure that students within distance education courses and programs had the opportunity to network and collaborate with peers and faculty was a crucial consideration for administrators in retaining students and developing essential professional skills. Drs. C and D expressed the need for student socialization and emphasized the importance of incorporating techniques and tools within distance education offerings to make sure students were able to develop social skills and networks. Both Drs. C and D agreed that many students today are already socially networkingusing Web 2.0 tools such as Facebook and MySpace and, therefore, have grown accustomed to networking online. To increase these networks, one professor was incorporating blogs, wikis, and a social networking site into the course curriculum to provide familiar social networking opportunities for students. Dr. D also found that when utilizing a synchronous videoconferencing tool, students "want to stay and linger after instructional time." Students in this class were collaborating about the course assignments and asking peers questions regarding lesson content. Dr. D went on to add that this experience was, "refreshing because it shows it [the course] is truly meaningful to them and that work and productivity are taking place even after the structured hours of direct instruction."

\subsection{Resources and External Support}

Resources and external support found within the decision making processes regarding distance education offerings included faculty support and training, student support, and external support.

Having the necessary support network and training opportunities for faculty responsible for incorporating technology into courses was very important to these administrators. Support networks such as using electronic mailing lists allowed faculty to communicate and solve problems collaboratively. Dr. D described the experiences of piloting new technology and emphasized how useful the electronic mailing list was in gaining ideas from interdisciplinary colleagues and for troubleshooting when difficulties occurred with 
the technology medium. Providing training and support for faculty learning to integrate these new technologies was emphasized in all of the interviews. Each of the four participants identified the university's learning and teaching center to provide such training opportunities.

When discussing his/her perception of the university's attitude regarding the implementation of distance education offerings, Dr. D believed the university had an expectation of faculty to integrate technology into their courses. Dr. D stated, "I really believe that we are encouraged... if you are up to the challenge, we [the university] will support you in this endeavor." This statement was contradicted by Dr. C's concerns that training and support services were limited and oftentimes difficult to obtain. According to Dr. C, the university's technology resource center, located on the main campus, provided training to faculty on the regional campus only when requested. Dr. C said, "they [the technology resource center] will travel to the regional campus, but it [the trainings] are not regularly offered here." This is a challenge for administrators as such resources should be readily accessible and are continuously needed for faculty who are motivated to explore them. Additionally, follow-up training for faculty should be conducted to ensure the tools provided were being utilized both efficiently and effectively. Dr. C also emphasized the importance of the follow-up by stating, "professional development by disseminating information is never enough." Administrators should invest in follow-up training and programming to confirm and support the skills faculty members have learned in training and ensure that the skills and knowledge are being integrated effectively into class instruction.

Student support in obtaining resources for distance education was another major concern of the administrators. Drs. C and D discussed the need for broadband Internet and the possibility of making access to broadband a course requirement. The challenge associated with this factor was the inability of students to find funds for obtaining this accessibility. When considering the geographic distribution of the student body, administrators were challenged with the realization that many of their students could not locate the needed broadband access because they lived in remote areas where these services were not available. The lack of access forced students to be creative in locating such resources within their communities. Dr. C provided the example of students utilizing work computers, library computers, and computers at K-12 schoolsthat have access to broadband Internet. As a result, student needs and the requirements set forth by the institution should be carefully considered in the program development stages, because without the needed technology support (or resources), students may be placed at an educational disadvantage.

External support was another expectation of the administrators. Dr. A explained that, "Universities encourage people to bring in grant funding because it helps fill the funding gap between what they need to exist and what they are given to exist by the state." In discussing the types of external funding sources available, Dr. A added, "The big picture for the college is to develop external funding sources that bring in funds from grants, alumni development, community businesses, and partnerships with entities that have a vested interest in our college's success."

Partnerships were another area of external support that impacted distance education decision making. Partnerships discussed included a global leader in interactive whiteboard technology and a Web-based course management system company. These partnerships were developed at the college and university levels. The partnership with 
the whiteboard company provided the college with donations of both equipment and training. In addition to the equipment and training, the whiteboard company also provided additional technology equipment at discounted prices. This partnership was one way administrators in this study obtained needed technology resources for both faculty and students. During the interview process, a newly-formed partnership with the course management system company was also being piloted. This company provided trainings for faculty on the utilization of their tools and technology as connected to the development of online courses. This partnership served as another example of how a company with a vested interest in the outcome of the institution can provide needed support to faculty and help administrators obtain the resources needed for faculty to be successful. Participants confirmed that long-term planning with technology partners should be explored and considered, as partnerships such as these can be great support mechanisms and resources for faculty and administrators developing distance education offerings.

\subsection{Lack of Funding and High Costs}

Lack of funding included the need to increase budget allocations to update computer equipment for faculty. Costs that were considered in decision making processes included those connected to students and faculty, as well as distance education courses and program costs. The participants in this study acknowledged the current ominous state of the national and local economies, while attempting to start and expand distance education. However, all of the interviewees were committed to integrating technology to improve instruction and develop additional distance education offerings. Dr. A commented, "It's pretty remarkable from the standpoint that we're in dire financial times and we have been able to reallocate resources to make this happen, showing the level of commitment the administration has to developing technology."

Expenses of distance education offerings, such as marketing materials, were another area of concern. Dr. D specifically addressed this issue by confirming the lack of funding available at the department level to advertise for distance education offerings. By thinking creatively, the administrators were able to partner with another department to send out informational packages that "provoked immediate responses." When making distance education decisions, administrators should investigate the most efficient and effective methods of marketing distance education offerings.

Student costs were another major concern of the administrators interviewed in this study. Student costs that were specifically discussed included Internet and essential equipment, such as a computer, software, headset with microphone and video camera, as well as online course fees. Additional concerns were expressed regarding the lack of financial aid available for students enrolled in distance education courses. Drs. C and D described their experiences with current distance education students who lacked the necessary equipment for class. According to them, there was no way for the online course to function effectively without this equipment.

Administrators in the study also considered faculty costs associated with distance education offerings. They believed that these costs should not only be a consideration of the faculty's department, but at all administrative levels, including college and upper-administration levels. If a faculty member was interested in incorporating technology in classroom content, or developing online courses, the tools needed to achieve this goal should be available and provided to that faculty member. They also considered updated equipment and/or the 
option of release time to develop instructional materials essential to the development of distance education offerings. After describing two faculty members who were working with antiquated systems to develop online courses, Dr. C stated, "If we expect people to put the courses online, then as a university we should be able to provide resources for those people." One current option available to faculty interested in building online courses or integrating technologies into existing curriculum is sabbatical leave. However, as finances become more strained and budget strings are reduced and eliminated, incentives such as sabbaticals become limited. Sabbatical demand, along with a lack of funding for online adjuncts and full-time faculty, produce "a real financial strain," according to Dr. A.

Additionally, questions have been raised regarding whether or not online faculty should be provided greater compensation due to increased student loads. If additional compensation is required, financial challenges will be exacerbated. But Drs. B and C expressed the belief that distance education offerings were less expensive than face-to-face courses, thereby reducing the budgetary demands. In discussing perspectives on developing distance education offerings, Dr. B made the following statement, "Distance education is a lot less expensive because you don't have to worry about brick and mortar costs. As a result, it seems like it would be feasible [to expand distance education offerings]."

\subsection{Administrative Considerations}

Administrative considerations that were discussed within the interviews included institutional bureaucracy and creating success stories.

Institutional bureaucracy had a significant impact on distance education offerings as reflected in the resultant barriers presented to faculty wishing to develop online courses or programs. All four participants discussed length of time and difficulty associated with getting distance education courses or programs approved. In discussing the barriers of institutional bureaucracy faced at the current institution, Dr. B commented that:
Some of the bureaucratic barriers need to be broken down because, as a result of the barriers, the university moves very slowly and technology moves very rapidly. So you need to have people in administrative roles who understand those conflicting dynamics and are willing to break down the barriers. Those who cannot understand will be left behind.

Another example of the impact of undue bureaucracywasduring the developmentofanew fully online program. This particular program's courses had previously been approved for online delivery; however, additional approval for the program had to be obtained because the proposal now included online delivery in greater than $50 \%$ of the program's courses. Dr. $\mathrm{C}$ described this process:

As you ready your faculty to accept the change of instructional delivery from faceto-face to online and then have them trained to use technology, you lose momentum when they have to wait for approvals to get going.... It's a barrier to have to restart the process. Getting the program approved for online delivery was a tremendous barrier that in my mind didn't have to be. 
Finally, administrators recognized the need to create faculty success stories to further develop distance education offerings. Drs. A and $\mathrm{B}$ identified that an essential administrative responsibility was to ensure that faculty were successful in their endeavors. Therefore, they stated, when a faculty member comes to an administrator with an idea or need, that administrator must be willing to listen and help the faculty member overcome any barriers and bring the idea to completion. In such a situation where an idea presents itself, a team of motivated faculty should be created and provided with the resources to make that idea or project a reality. Dr. A believed that, "By creating a success story, others will see that success as a model and want to replicate it."

\section{Discussion}

Findings from this study confirmed six emerging themes that should be considered in administrative decision-making processes: (a) distance education offerings, (b) faculty considerations and incentives, (c) student considerations, (d) resources and external support, (e) lack of funding and costs, and, (f) administrative characteristics and considerations.

Among the identified themes, faculty considerations and incentives as well as student considerations were the most important to the administrators who participated in this study. Each of the participants discussed these themes in depth and believed that decisions regarding distance education offerings should take these factors into consideration. Faculty considerations discussed included tenure and promotion policies and procedures, buy-in, openness/resistance to online learning, and academic rigor. The findings from this study were consistent with the research of Dooley and Murphrey (2000), Hislop and Ellis (2004),
Maguire (2005), and Howell, Williams, and Lindsay (2003). The research also indicated that faculty concerns regarding tenure and promotion policies and procedures was a significant factor pertaining to distance education. The findings of this study were also consistent with those of Bernard and Abrami (2004), Howell et al. (2003), and McLean (2005) in that they found resistance to online learning as a significant factor impacting distance education. Moreover, the findings of this study showed academic rigor as another significant factor impacting distance education. These were consistent with the findings of Hislop and Ellis (2004) and Chick et al. (2002).

Resources and external support as well as lack of funding and costs were ranked second to faculty and student considerations. While allocating sufficient funding for distance education offerings is important, without an interested student base and faculty who are motivated to integrate and develop distance education offerings, there is little need for funding such endeavors. The need for faculty support and training was consistent with the research of Portugal (2007). The importance of obtaining external support was also consistent with the findings of Howell et al. (2003). While external support has played a minor role to this point in distance education offerings, the lack of funding available for higher education institutions might place an increased emphasis on securing external funding. Student support was also discussed within current research; however, most literature identified the types of services needed to support students, while the findings of this study focused on financial support and costs for equipment for distance education coursework.

Lack of funding considerations included the need to increase budget allocations for updated computer equipment. Additionally, financial support to provide a greater number of 
adjunct faculty members as support was also a consideration within the lack of funding theme. Updated equipment and financial support for new faculty were supported by the research of others, including budgeting allocations for updated computer equipment (Bower, 2001) and faculty workload creating the need for additional faculty (Maguire, 2005). The need for additional equipment for adjunct faculty was not supported in the literature. As higher education budgets and tenure track faculty positions continue to decrease, further study on the needs of adjunct faculty members should be explored.

Administrative considerations were also identified as extremely important, particularly in the area of institutional bureaucracy. Providing processes that encourage distance education offerings as opposed to those that prohibit the expansion of offerings is critical. Previous literature supported both institutional bureaucracy (Aggarwal \& Makkonen, 2009; Irele, 2005) and time constraints (Hislop \& Ellis, 2004), which have also been identified as administrative considerations that impacted distance education offerings. Creating success stories to positively impact faculty attitudes regarding distance education offerings and integrating technology was not supported by the literature. The identified gap in the literature could be due to a personal philosophy that one specific administrator within the study had; therefore, this concept should be evaluated to determine whether or not administrators are utilizing this practice as a way to encourage the development of distance education offerings.

This study further identified that over $70 \%$ of the faculty were junior faculty at the university. Enticing faculty to integrate technology and develop distance education offerings will continue to be a struggle if tenure and promotion policies and procedures are not further explored and revised. Administrators were primarily concerned with incentives in place for faculty because of the level of importance placed on faculty considerations. Findings indicate that further investigation on tenure and promotion policies and procedures should be conducted. Additionally, discussions with upper administration to support policy change which encourages faculty incorporation of technology and distance education development should be conducted. Without providing faculty with the incentives needed to work towards the common goals of expanding distance education offerings, the administrators in this study will continue to be challenged by this factor.

While this research study confirmed many existing factors found in previous research, the findings also identified a several new ones. Based on this study, best practices should be identified to provide guidance and awareness of these factors and strategies to overcome any barriers they may help create.

\section{Recommendations}

Based on the findings from this study, the following recommendations are provided to help administrative decision making regarding distance education offerings. Administrators should consider faculty and student considerations in decision making for distance education offerings. Faculty support is critical when creating and expanding distance education offerings. Administrators need to also consider faculty incentives currently in place to determine whether or not these incentives provide motivation for faculty to engage in distance education offerings.

Student considerations also impact decision making for distance education. Establishing the needs of the students and setting goals accordingly are important. For example, if students are seeking fully online courses and 
the department only offers hybrid courses, there is a mismatch of offerings to accommodate student needs which can negatively impact the distance education program(s). Further, the cost associated with integrating technology and creating and expanding distance education offerings can be high compared to traditional offerings, therefore ensuring those technologies deployed actually meet the needs of the students enrolled in the program(s) will help administrators practice good fiscal responsibility.

Institutional bureaucracy is the next important factor to be considered. When administrators decide to create and/or expand distance education offerings, having a solid understanding of the university's institutional policies and processes is important. This will allow administrators to prepare for the institutional processes that will be required ahead of time as well as establish a realistic timeline for the creation/expansion of distance education offerings.

While the findings of this study should not make generalizations about southeastern research-intensive universities, the themes found were in support of challenges associated with decision making in distance education. Additionally, administrators should explore the themes discussed to assess the level of importance these themes have at their individual institutions. The findings of this study provide initial factors which can be used in collaborative discussions with both faculty and upperlevel administration to help improve distance education processes currently in place.

In relation to organizational change, administrators should be trained to effectively navigate through institutional processes to alleviate institutional barriers that serve as a hindrance to the expansion of distance education offerings. The administrators in this study found the institutional processes in place as barriers to developing distance education offerings. By understanding institutional administrative policies and procedures, prior to the development of distance education offerings, administrators can evaluate processes that are ineffective, inefficient, or even barriers to the creation and expansion of distance education offerings.

Finally, administrators should consider the review of tenure and promotion processes related to distance education and how those policies impact the future of the field. Updated tenure and promotion policies and procedures that provide incentives for integrating technology and developing distance education courses should be further explored by administrators. Many institutions have integrated technology enhancements within the classroom as well as distance education development into tenure and promotion policies and procedures. However, there are many institutions that lack incentives which recognize faculty for technology integration and development of distance education offerings; therefore, there are prevailing concerns for those faculty in tenure track faculty lines. Without an incentive to support the growth of technology within the classroom and distance education development, administrators will find it difficult to grow and/or expand current distance education offerings.

\section{Conclusions}

The findings of this study confirmed the four factors identified by the previous studies, (a) faculty concerns, (b) institutional barriers, (c) lack of funding/costs and resources, and (d) external support in administrative decision making, impacted decision-making regarding distance education. Among these factors, faculty and student considerations were the two factors that were discussed by every participant 
as important considerations to administrative decision-making. Major themes developed from interviews with administrators supported current distance education challenges. While the level of impact that these areas had on distance education offerings varied for each administrator, each of the themes identified influenced the administrators' decision making.

By understanding the factors that key administrators need to consider, universities can plan, prepare, and revise distance education policies and procedures to alleviate some of the current barriers in expanding distance education offerings. This study can serve as a starting point for future quantitative research studies to identify the levels of importance each theme has on the implementation or expansion of distance education. Quantitative analysis will also determine whether or not these themes are unique to the institution studied or prominent in institutions throughout the southeastern region. By actively exploring the administrative decision making processes involved in distance education, administrators will better understand the challenges the field presents and develop best practices for future distance education endeavors. Through these activities, the field of distance education will continue to grow and expand.

\section{References}

Aggarwal, A. K., \& Makkonen, A. (2009). Critical success factors for globalised e-learning. International Journal of Innovation and Learning, 6(1), 92-109.

Anderson, R. E., \& Dexter, S. (2005). School technology leadership: An empirical investigation of prevalence and effect. Educational Administration Quarterly, 41(1), 49-82.

Bernard, M., \& Abrami, P. C. (2004). How does distance education compare with classroom instruction? A metaanalysis of the empirical literature. Review of Educational Research, 74(3), 379-439.

Bower, B. L. (2001). Distance education: Facing the faculty challenge. Online Journal of Distance Learning Administration, 4(2), 1-6.

Chick, S., Day, R., Hook, R., Owston, R., Warkentin, J., Cooper, P. M., et al. (2002). Technology and student success in higher education: A research study on faculty perceptions of technology and student success. Toronto, Ontario: McGraw-Hill Ryerson.

Dooley, K. E., \& Murphrey, T. P. (2000). How the perspectives of administrators, faculty, and support units impact the rate of distance education adoption. Online Journal of Distance Learning Administration, 3(4). Retrieved April 30, 2009, from http://www. westga.edu/ distance/ojdla/winter34/ dooley34.html.

Guba, E. G., \& Lincoln, Y. S. (1994). Competing paradigms in qualitative research. In N. K. Denzin \& Y. S. Lincoln (Eds.), Handbook of qualitative research, (pp. 105-107). Thousand Oaks, CA: Sage.

Hislop, G. W., \& Ellis, H. J. (2004). A study of faculty effort in online teaching. The Internet and Higher Education, 7(1), 1531.

Howe, N., \& Strauss, W. (2003). Millennials \& K-12 Schools. Great Falls, Virginia: LifeCourse Associates,

Howell, S. L., Williams, P. B., \& Lindsay, N. K. (2003). Thirty-two trends affecting distance education: An informed foundation for strategic planning. Online Journal of Distance Learning Administration, 6(3). Retrieved April 30, 2009, from http:// www.westga.edu/ distance/ojdla/fall63/ howell63.html

Irele, M. (2005). Can distance education be mainstreamed? Online Journal of 
Distance Learning Administration, 8(2). Retrieved September 8, 2009, from: http:// www.westga.edu/\%7Edistance/ojdla/ summer82/irele82.htm

Leedy, P., \& Ormrod, J. (2005). Practical research: Planning and design ( $6^{\text {th }}$ ed.). Upper Saddle River, New Jersey: Pearson Education Inc.

Maguire, L. L. (2005). Faculty participation in online distance education: Barriers and motivators. Online Journal of Distance Learning Administration, 8(1). Retrieved April 30, 2009, from http://www.westga. edu/ distance/ojdla/spring81/maguire81. htm

McLean, J. (2005). Addressing faculty concerns about distance learning. Online Journal of Distance Learning Administration, 8(4). Retrieved April 30, 2009, from http://www.westga.edu/ distance/ojdla/ winter84/mclean84.htm
Portugal, L. M. (2007). Emerging leadership roles in distance education: Current state of affairs and forecasting future trends. Academic Leadership Journal 4(3). Retrieved September 1, 2009, from http://www.academicleadership.org/ index.shtml

Punch, K. F. (2000). Introduction to social research: Quantitative \& qualitative approaches. Thousand Oaks, CA: Sage Publications.

Shim, M. K., \& Shim, S. J. (2001). Mobile computing in higher education: Faculty perceptions of benefits and barriers. Journal of Educational Technology Systems, 29(4), 345-354.

Surry, D. W., \& Land, S. M. (2000). Strategies for motivating higher education faculty to use technology. Innovation in Education and Training International, 37(2), 145153. 


\section{Appendix A: Guided Interview Questions}

1. Background Information

a. How long have you been working in higher education?

b. How long have you been in a leadership role?

c. Define your current situation regarding distance education offerings. Are there any opportunities currently available? What types of offerings (video conferencing, online, etc.)?

2. Faculty Concerns

a. What types of faculty concerns do you have when it comes to distance education?

b. Can you provide me a specific example of some of these concerns?

c. What is the department/college's general view on distance education?

d. How have you been able to address these concerns?

e. How do these impact your departmental/ administrative decisions concerning distance education offerings?

3. Institutional Barriers

a. What types of challenges do you have on an institutional level?

b. Do you have any examples of barriers you, your faculty, or your college have experienced with implementing distance education offerings?

c. Which barrier, if any, do you think would improve the ability of your department/ college in creating/expanding its distance education offering?

d. Are there administrative processes that need to be considered when deciding on creating/ expanding distance education offerings?

4. Lack of Funding/Costs

a. How are your faculty compensated for distance education offerings?

b. Does the department receive any funding support from the college or institution for creating/ expanding distance education offerings?

c. How does the costs of your distance education offerings impact your decision in whether or not to start and/or expand your current distance education offerings?

5. Resources/External Support

a. What types of resources are available for interested faculty in regard to distance education offerings?

b. Are there external funding opportunities for faculty interested in implementing distance education offerings?

c. Is there training provided at the department/college/ institution level?

d. Are there facilities and technological resources for faculty to implement the technologies they determine best suited for distance education offerings?

e. What do you believe is the overall perception of distance education offerings in the community? State of Mississippi? Institutes of Higher Learning?

f. What types of resources, if any, do you feel would help facilitate the creation/ expansion of distance education offerings?

6. Additional Information

a. Is there anything else in relation to distance education offerings that you would like to share? 


\section{Contact the Authors}

Jennifer L. Styron, M.Ed.

The University of Southern Mississippi, USA

E-mail: Jennifer.Styron@usm.edu

Shuyan Wang, Ph.D.

The University of Southern Mississippi, USA

E-mail: Shuyan.Wang@usm.edu

Ronald A. Styron, Jr., Ed.D.

The University of Southern Mississippi, USA

E-mail: Ronald.Styron@usm.edu 